\title{
Erratum to: Monitoring the diel activity of Ixodes ricinus ticks in Hungary over three seasons
}

\author{
Viktor Zöldi · Jenő Reiczigel • László Egyed
}

Published online: 5 July 2013

(C) Springer Science+Business Media Dordrecht 2013

\section{Erratum to: Exp Appl Acarol DOI 10.1007/s10493-013-9708-4}

Due to an unfortunate turn of events, the second author's surname appeared incorrectly in the original publication and should have read Reiczigel. The correct representation of the authors' names is listed above and below and should be treated as definitive by the reader.

The online version of the original article can be found under doi:10.1007/s10493-013-9708-4.

V. Zöldi $(\bowtie)$

Department of Vector and Public Health Pest Control, National Center for Epidemiology, Gyáli út 2-6, 1097 Budapest, Hungary

e-mail: zoldi.viktor@oek.antsz.hu

J. Reiczigel

Department of Biomathematics and Informatics, Faculty of Veterinary Science,

Szent István University, P.O. Box 2, 1400 Budapest, Hungary

L. Egyed

Institute for Veterinary Medical Research, Centre for Agricultural Research,

Hungarian Academy of Sciences, P.O. Box 18, 1581 Budapest, Hungary 